\title{
The influence of the parameter $\gamma$ choice on the variation of the pressure and flow rate, when the valve is closed at the end by the gravity feeding of the pipeline
}

\author{
B. Hoggas • C. Hezil \\ Moustapha ben Boulaid University of Batna - 2, Batna, Algeria
}

Received: 24 November 2017 / Accepted: 02 December 2017

\begin{abstract}
A study of the change in pressure and flow in a pipeline that is connected to a tank (point B) having a constant water level for the entire time of the transition mode phenomenon, which occurs during the closure of the valve located at the end of the horizontal gravity of the pipeline (point A). Closing of this valve is performed in three ways - instantaneous, sudden and slow mode, the closing operation of the valve is expressed through a function of the time t and the parameter $\gamma$, characterizing the form of closing the section of this valve, $\gamma$ can vary in the interval [0,7-1,5]. Variables of pressure and water flow rate at points $\left(Q_{t}^{A}, H_{t}^{A}\right),\left(Q_{t}^{B}, H_{t}^{B}\right) u\left(Q_{t}^{c}, H_{t}^{c}\right)$, at any instant $t$, respectively, to the gate valves, the tank and in the middle of the pipeline (point $C$ ), will be determined in two ways, the graphical method is the well-known Bergeron method, and the second is the analytical method of characteristics.
\end{abstract}

Keywords: the transition mode; gravity of the pipeline; instantaneous, sudden and slow mode; Pressure and flow variables; Bergeron graphical method; analytical method of characteristics.

\section{Introduction}

The aim of this study is to analyze the pressure and flow rate variations of a horizontal pipe, connected upstream to tank point B, ( Fig. 1.). These variations occur during a transient regime [1] and result from the excitation of a valve at point A ( Fig. 1), located at the downstream end of this pipe, which is closed in three ways either instantaneously, sudden and slow mode, and gives rise to a transient flow regime along the pipe. The closing of the valve takes place according to a law which is a function of time $t$ and a parameter $\gamma:\left(\eta=\left(1-\frac{t}{t_{c l}}\right)^{\gamma}\right)$, that characterizes the shape of the variation in the obstruction of the section $\omega$ of the valve [2]. The degree of closing is a parameter $\eta$ that changes from 0 down to 1 according to the state of the valve. For an initial time $(t=0)$, the degree of closing is equal to unity $(\eta=1)$, this means that the valve is completely open. Whereas for $\left(t=t_{c l}\right)$, the valve is closed and the parameter is equal to zero ( $\eta=0$ ). This is valid for the three cases: $\gamma=1.5, \gamma=1, \gamma=0.7$ [2]. Nevertheless, in the time interval $\left(0+\varepsilon<\mathrm{t}<t_{c l}-\varepsilon\right)$, each case changes differently. For the first case having an exponent greater than unity $(\gamma>1)$, the change of the closing degree leads to rapid decreasing sections at the beginning of opening but later at the end of closing the decrease of sections is slower. On the other hand, when $(\gamma=1)$, the degree of closing is linear having a shape of a straight line: $a x+b$, with slope: $-\frac{1}{t_{c l}}$, this implies that the opening sections vary in the same way. Finally, the opposite occurs for the third case, whose exponent is less than unity $(\gamma<1)$, the variation of parameter $\eta$, increases rapidly at the end of the closure and slowly near the beginning of maneuver [3,4]. The opening cross-sections of the valve in the time interval $0+\varepsilon<\mathrm{t}<$ $t_{c l}-\varepsilon$, for an exponent greater than unity $\gamma=1.5$ are less than those in the case of a $(\gamma=1)$. The inverse occurs for the case of an exponent smaller than unity $(\gamma=0.7)$, where the aperture sections are much larger than the first two cases $(\gamma=$ 1.5 and $\gamma=1$ ), (Fig. 2).

The variables at the points $\left(Q_{t}^{A}, H_{t}^{A}\right),\left(Q_{t}^{B}, H_{t}^{B}\right)$ et $\left(Q_{t}^{C}, H_{t}^{C}\right)$, at any moment in time t, that are located, respectively, at the valve, at the tank and at the middle of the pipe, will be determined using two methods. The first one is graphical and called Bergeron method where the variables are determined in the Q, H plan [5, 3]. The second one is analytical and called method of characteristics [6, 7], in this method the variables are determined in the $x, t$ plan [8]. These two methods are applied for the three parameters $\gamma=1.5, \gamma=1$ and $\gamma=0.7$, with the same closing time, expressed as a phase $t_{c l}=2 \theta$. 


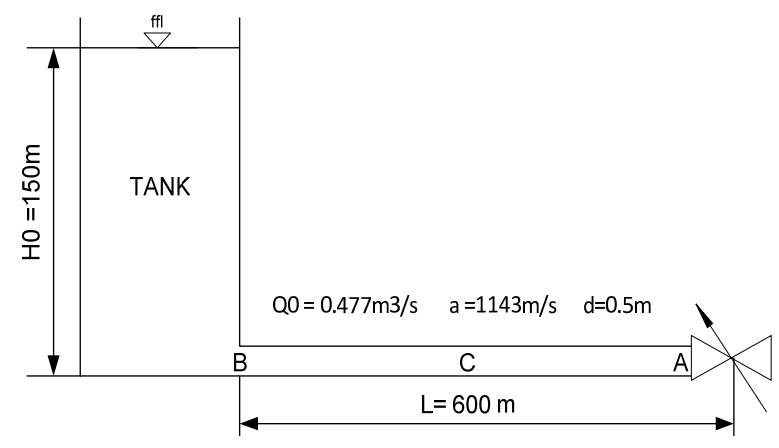

Fig. 1. Gravity feeding pipe with unique characteristic

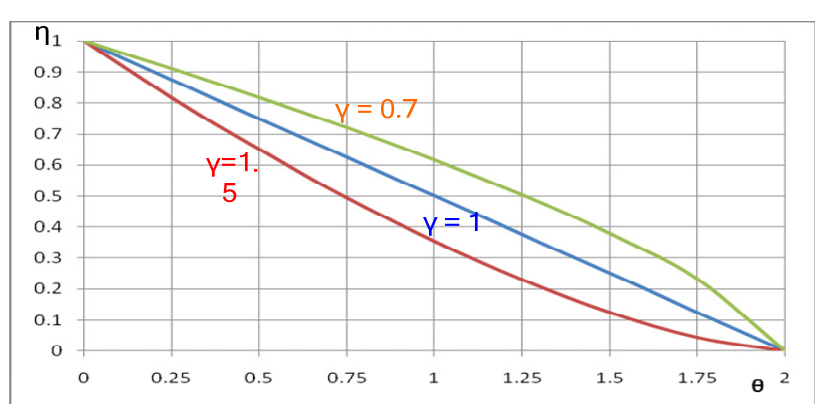

Fig. 2. Time variation of the closing degree, $\eta=f(t)$

We report on (Table 1), the geometrical and cinematical data, the initial conditions of the studied pipe and also the results of the variation calculations of the valve closing degree $\eta$.

Data and initial conditions of pipeline with unique characteristic

\begin{tabular}{|c|c|c|c|c|c|c|}
\hline \multicolumn{2}{|c|}{$H_{0}=150 \mathrm{~m}$} & $\begin{array}{c}Q_{0}=0.477 \\
\mathrm{~m}^{3} / \mathrm{s}\end{array}$ & $\begin{array}{c}\text { Wave } \\
\text { propagation } \\
\text { speed : } \\
\mathrm{a}=1143 \mathrm{~m} / \mathrm{s}\end{array}$ & $\mathrm{L}=600 \mathrm{~m}$ & $\mathrm{D}=0.5 \mathrm{~m}$ & $\omega=0.19625 \mathrm{~m}^{2}$ \\
\hline \multicolumn{2}{|c|}{$\begin{array}{c}\text { Degree of } \\
\text { closing of the } \\
\text { valve for each } \\
\text { phase } \\
\eta=\left(1-\frac{\mathrm{t}}{\mathrm{tf}}\right)^{\gamma}\end{array}$} & $\begin{array}{c}\text { The equation that } \\
\text { expresses the } \\
\text { closing of the } \\
\text { valve } \\
Q_{t}=Q_{0} \eta\end{array}$ & $\begin{array}{l}\text { The time of } \\
\text { a phase in } \\
\text { seconds } \\
\begin{array}{c}\theta=2 L / a \\
=1.05 \mathrm{~s}\end{array}\end{array}$ & $\begin{array}{c}\text { Closure time } \\
\text { expressed in } \\
\text { phase } \\
t_{f}=2 \theta\end{array}$ & \multicolumn{2}{|c|}{$\begin{array}{l}\text { Closing time in seconds } \\
\qquad t_{f}=2.1 \mathrm{~s}\end{array}$} \\
\hline \multicolumn{7}{|c|}{ Time variation of the valve closing degree } \\
\hline & $\theta$ & 0 & 0.5 & 1 & 1.5 & 2 \\
\hline \multicolumn{2}{|c|}{$t=\theta:[\mathrm{s}]$} & 0 & 0.525 & 1.05 & 1.575 & 2.1 \\
\hline \multirow{3}{*}{$\eta$} & $\gamma=1$ & 1 & 0.75 & 0.5 & 0.25 & 0 \\
\hline & $\gamma=1.5$ & 1 & 0.64952 & 0.35355 & 0.125 & 0 \\
\hline & $\gamma=0.7$ & 1 & 0.817604 & 0.615572 & 0.378929 & 0 \\
\hline
\end{tabular}

Purpose of the study : The aim of this work is to determine the variables $Q_{t}^{A}, H_{t}^{A}, Q_{t}^{B}, H_{t}^{B}$, and $Q_{t}^{C}, H_{t}^{C}$ at any moment in time [8], using two methods in order to validate the calculation results and to study the influence of these three values of the parameter $(\gamma)$ on the pressure and flow rate variables at the points $\mathrm{A}, \mathrm{B}, \mathrm{C}$, for the same closing time say : $t_{c l}=2 \theta$. We also perform an analysis for the first case $(\gamma=1.5)$ that will be applied for four different closing times $t_{C l}=0.25 \theta, \theta$, (sudden) and $2 \theta, 3 \theta$ (slow). All this in order to see the impact of the closing time on the variations of variables at points $\mathrm{A}, \mathrm{B}, \mathrm{C}$. The characteristic curves for each considered time are expressed in term of phase that will be represented by the function (3): $\psi_{0} \psi_{0.5 \theta}, \psi_{\theta}, \psi_{15 \theta}, \psi_{2 \theta}$, (fig. 3). Exponents of the closing equation given by supplier: $\gamma$ $=1.5, \gamma=1$ and $\gamma=0.7$, for each type of valve [2]. The complete opening condition of the valve is referred by the function $\psi_{0}(3)$, at the initial time, before excitation, the curve of $\psi_{0}$ must meet the tank characteristic at ordinateH $\mathrm{H}_{\mathbf{0}}$, with respect to the pipe axis, and abscissa $\mathrm{Q}_{0}$, this pressure load $\mathrm{H}_{0}$ is constant all the way of the valve closing operation and during the transient regime of water hammer effect for the three cases.

The flow rate through the valve at any point in time can be considered as a flow through an orifice and can be written as follows:

$$
Q_{t}=C_{t} \omega_{t} \sqrt{2 g H_{t}}
$$

$C_{t}$ : Flow coefficient; $\omega_{t}$ : Instantaneous pipe cross section in time $t ; H_{t}$ : Pressure load, on top of the water column, in meters, exerted on valve in time t. Complete opening corresponds to permanent regime $\left(Q_{0}, H_{0}\right)$, the equation is:

$$
Q_{0}=C_{0} \omega_{0} \sqrt{2 g H_{0}} \text {. }
$$

The load $H_{0}$ is maintained at a constant level, with_respect to the horizontal axis of the pipe. During the closing of the valve, in an instant of time $t$, the initial cross section $\omega_{0}$ decreases and becomes equal to $\omega_{t}$. The speed in this time point $\mathrm{t}$, decreases, which leads to a pressure variation equal to $\Delta \mathrm{H}$, with respect to the initial load $H_{0}$. That is why the pressure $H_{t}$ becomes equal to: $H_{t}=H_{0}+\Delta \mathrm{H}$. The variation of the flow rates in permanent and transient regimes leads to a 


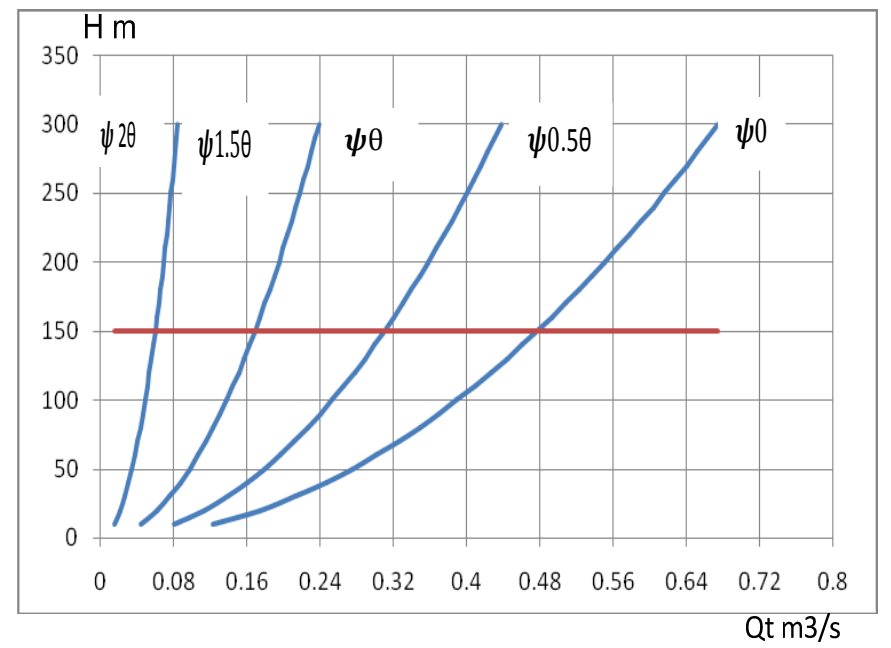

Fig. 3. Characteristic curves of a valve closing in a time $t_{c l}=2 \theta$, for $\gamma=1.5$

proportionality coefficient $\eta$, which depends on valve closing degree, on the shape, on the cross section variation of the obstruction at time $t$ and that depends also on the coefficient $\gamma$, that will be given by the supplier for. The cross section $\omega_{0}$ and the closing degree coefficient must be equal to unity: $\eta=1$ at time: $t=0$ and for a complete closing, the coefficient vanishes $\eta=0$ at the time: $\mathrm{t}=t_{c l}$, that's why this coefficient must be within the interval $0 \leq \eta \leq 1$. Then from (1) and (2) we have:

$$
Q_{t}=k_{t} \sqrt{H_{t}},
$$

where : $K_{t}=\frac{\eta Q_{0}}{\sqrt{H_{0}}} ; \eta=\frac{c_{t} \omega_{t}}{c_{0} \omega_{0}}$. The results of $K_{t}$, are reported on Table 2 . The closing is said to be instantaneous when $t_{c l}$. $\approx 0$, it is said sudden (progressive) for : $0<t_{c l} \leq \theta$, it is said slow when $t_{c l}>\theta$. The phase $\theta$ is the time necessary for a wave to perform, at the time of excitation (either accidently or willingly) a round trip and return to the valve $[8]: \theta=2 L / a=1.05 \mathrm{~s}$.

Bergeron graphical method. In the case of a horizontal axis pipe which is positively oriented in the opposite direction to the flow and having a single characteristic connected upstream by a reservoir at point $\mathrm{B}$, the load of which at this point, with respect to water plan, is constantly equal to $H_{0}=150 \mathrm{~m} \mathrm{H}$, downstream of this pipe and at its end there is a valve at point $\mathrm{A}$, which is forced to close for 2.1 seconds, say of phases $2 \theta$.

Table 2

Time variation of the closing degree of the valve and flow rate, for $\gamma=1.5$

\begin{tabular}{|c|c|c|c|c|c|}
\hline$\eta$ & \multirow{2}{*}{$H_{0} \mathrm{~m}$} & $Q_{0} \mathrm{~m} 3 / \mathrm{s}$ & $\eta Q_{0}$ & $\sqrt{H_{0}}$ & \multirow{2}{*}{$K_{t}=\frac{\eta Q_{0}}{\sqrt{H_{0}}}$} \\
\hline$y=1.5$ & 150 & 0.477 & 0.477 & 12.2475 & 0.03894672 \\
\hline 1 & 150 & 0.477 & 0.30982 & 12.2475 & 0.02529659 \\
\hline 0.64952 & 150 & 0.477 & 0.16864 & 12.2475 & 0.01376934 \\
\hline 0.35355 & 150 & 0.477 & 0.0596 & 12.2475 & 0.0048663 \\
\hline 0 & 150 & 0.477 & 0 & 12.2475 & 0 \\
\hline
\end{tabular}

Bergeron graphical method [5], allows us to determine the evolution of the variables $\mathrm{H}, \mathrm{Q}$ during the transient regime of the flow. For instance, at the point $A: A_{0.5 \theta}, A_{1 \theta}, A_{1.5 \theta}, A_{2 \theta}$ and $A_{2.5 \theta}$, at the point $B: B_{0.5 \theta}, B_{1 \theta}, B_{1.5 \theta}$, $\mathrm{B}_{2 \theta}$ and $\mathrm{B}_{2.5 \theta}$ and at the point $\mathrm{C}: \mathrm{C}_{0.75 \theta}, \mathrm{C}_{1 \theta}, \mathrm{C}_{1.25 \theta}, \mathrm{C}_{1.5 \theta}$ et $\mathrm{C}_{1.75 \theta}$. The graphical Bergeron results are shown in Fig. 4.

The variables $\left(\boldsymbol{Q}_{\boldsymbol{\theta}}^{\boldsymbol{A}}, \boldsymbol{H}_{\boldsymbol{\theta}}^{\boldsymbol{A}}\right)$ at $\mathbf{t}=\boldsymbol{\theta}:$ In order to determine the variables $H_{\theta}^{A}$ and $Q_{\theta}^{A}$ at point $\mathrm{A}$, of the transient regime of the flow, at time $t=\theta$, one needs simultaneously two equations. The first one is the equation of the characteristic $\psi_{\theta}(3)$. The second, is the equation of the negative characteristic of the Bergeron line with a negative slope: $\operatorname{tg} \alpha=-a g / \omega$, in the Q,H plan. For which the man of Bergeron [5], moves at the propagation speed of forward wave (+a), according to the characteristic $\mathrm{c}+$, in the $(\mathrm{x}, \mathrm{t})$ plan, starting from the point $\mathrm{B}$ at the time $\mathrm{t}=0.5 \theta$, in the positive direction of the flow in order to join the valve, at point $\mathrm{A}$, at $\mathrm{t}=\theta$, whose closing degree at this moment is à $35.35 \%$ of full the section $\omega_{0}$ (Table 1 ), for $\gamma=1.5$. The flow regime at point $\mathrm{B}$ at $\mathrm{t}=0.5 \theta$ remains permanent, because the backward wave lasts half a phase starting from the point $\mathrm{A}$, to reach point $\mathrm{B}$. The two equations can be written as follows. The first is represented by the function $\psi_{\mathrm{t}}: Q_{\mathrm{t}}=k_{\mathrm{t}} \sqrt{H}$. The second is the equation of Bergeron line with negative slope:

$$
H_{0.5 \theta}^{B}-H_{\theta}^{A}=-\operatorname{tg} \alpha *\left(Q_{0.5 \theta}^{B}-Q_{\theta}^{A}\right) \text {. }
$$



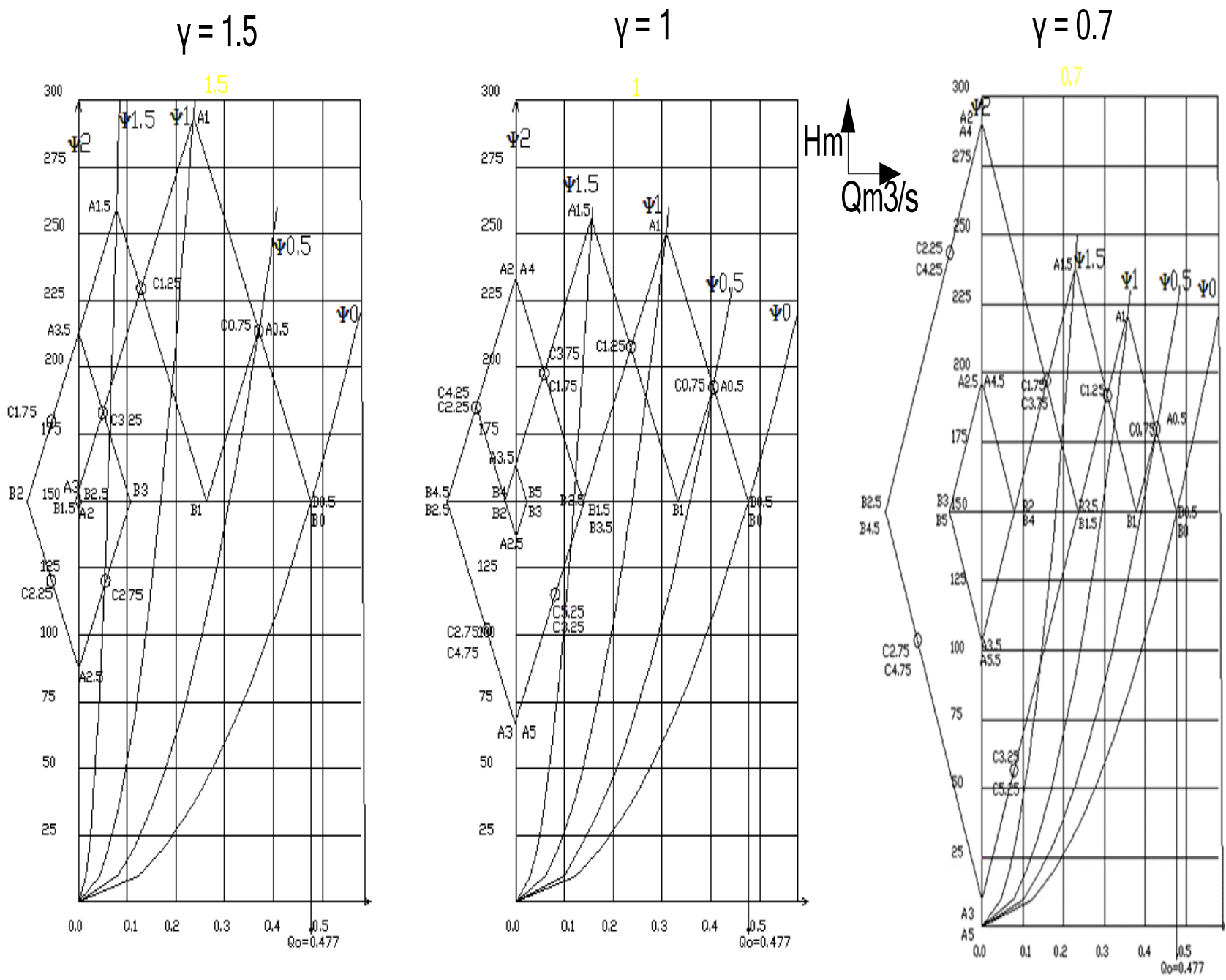

Fig. 4. Pressures and flow rates using Bergeron graphical method at points A (valve), B (reservoir) and C (middle of pipe) versus time in $\mathrm{H}, \mathrm{Q}$ plan, for $\gamma=1.5, \gamma=1$ and $\gamma=0.7$

The determination of these two variables is essentially based on the graphical Bergeron method (Fig.4). The intersection of Bergeron line passing through the point $\mathrm{B}$, being in the permanent regime, of coordinates $\left(H_{0}, Q_{0}\right)$, at time $0.5 \theta$ and with slope: $\operatorname{tg} \alpha=-a g / \omega$, with the function $\psi_{\mathrm{t}=\theta}$. The intersection of the two functions determine the coordinates of these two variables $Q_{\theta}^{A}, H_{\theta}^{A}$, in the $\mathrm{H}, \mathrm{Q}$ plane, at $\mathrm{t}=\theta$. The same technique is used for the variables at any intermediate time $H_{0.5 \theta}^{A}, Q_{0.5 \theta}^{A}$.

The variables $Q_{\mathbf{0 . 5 \theta}}^{A}, \boldsymbol{H}_{\mathbf{0 . 5 \theta}}^{A}$ at $\mathrm{t}=\mathbf{0 . 5 \theta}$ : In order to determine these two variables, one needs the characteristic $\psi_{0.5 \theta}$ and the same negative characteristics of the Bergeron line, with negative slope $\operatorname{tg} \alpha=-a g / \omega$, in the Q, H plan, for which the man of Bergeron moves with the same forward propagation speed (+a), according to the characteristic $C^{+}$, in the $\mathrm{x}, \mathrm{t}$ plan, starting from point $\mathrm{B}$ at $\mathrm{t}=0$, in the forward direction of the flow to reach the valve, located at point $\mathrm{A}$, at $\mathrm{t}=0.5 \theta$ and whose closing degree at this point of time is à $64.95 \%$ of the full cross section $\omega_{0}$ (Table 1 ), for $\gamma=1.5$. The Bergeron straight line will pass through the point $\mathrm{B}$ at $\mathrm{t}=0$, whose flow regime, at this point of time, is still permanent (initial), respectively the abscissa and the ordinate $\left(Q_{0}^{B}, H_{0}^{B}\right)$. The intersection of these two characteristics determines the variables $Q_{0.5 \theta}^{A}, H_{0.5 \theta}^{A}$ in the $\mathrm{Q}, \mathrm{H}$ plan at $\mathrm{t}=0.5 \theta$.

The variables $Q_{\theta}^{B}, H_{\theta}^{B}$ at $\mathbf{t}=\boldsymbol{\theta}:$ Knowing the flow regime at point $\mathrm{A}$ of the variables predetermined $Q_{0.5 \theta}^{A}, H_{0.5 \theta}^{A}$, the man of Bergeron arriving to point $\mathrm{A}$ at time $\mathrm{t}=0.5 \theta$, must return back in a positive characteristic of Bergeron straight line, in the $\mathrm{Q}, \mathrm{H}$ plan, and according to a negative characteristic $\mathrm{C}-$, in the $\mathrm{x}, \mathrm{t}$ plan backward. Its motion with a celerity that lasts half a phase to reach the point $\mathrm{B}$ at time $\mathrm{t}=\theta$. This line crosses the horizontal load plan with constant height $\mathrm{H}=H_{0}$, giving the variables $Q_{\theta}^{B}, H_{\theta}^{B}$, the variable $H_{\theta}^{B}$ must be in the same plan and must be equal to $H_{0}$ (permanent regime). The values of these determined variables will be used as initial conditions to determine the flow regime in the point $\mathrm{A}$ at $\mathrm{t}=1.5 \theta$.

The variables $Q_{1.5 \theta}^{B}, H_{1.5 \theta}^{B}$ at time $\mathbf{t}=1.5 \theta$ : Knowing the flow regime at point A of predetermined variables $Q_{\theta}^{A}, H_{\theta}^{A}$, located at the interse, when the the man of Bergeron arrives at point $\mathrm{A}$ at $\mathrm{t}=\theta$ it returns back following a positive characteristic of the Bergeron line, in the $\mathrm{Q}, \mathrm{H}$ plan according to a negative characteristic $C^{-}$, in the $\mathrm{x}$, t plan, with a celerity 
a that will last half a phase to arrive at point $\mathrm{B}$ at $\mathrm{t}=1.5 \theta$, the intersection of this line with the invariable horizontal load plan with constant height $\mathrm{H}=H_{0}$, gives the variables $Q_{1.5 \theta}^{B}, H_{1.5 \theta}^{B}$, the variable $H_{1.5 \theta}^{B}$ must be on the same plan and thus equal to the initial load $H_{0}$ (permanent regime). The determined variables will be used as initial conditions in order to find the flow regime at point $\mathrm{A}$ at $\mathrm{t}=2 \theta$. The procedure will be done for both points $\mathrm{A}$ and $\mathrm{B}$ at equidistant times separated by an interval equal to half a phase until the phenomenon repeats in an identical indefinite manner, due to the absence of pressure drops.

The obtained results are reported in table 3.

Table 3

Variation of pressure and flow rate at points $A$ and $B$

\begin{tabular}{|c|c|c|c|c|c|c|c|c|c|c|c|c|}
\hline \multirow{3}{*}{$\theta$} & \multicolumn{4}{|c|}{$\gamma=1.5$} & \multicolumn{4}{|c|}{$\gamma=1.0$} & \multicolumn{4}{|c|}{$\gamma=0.7$} \\
\hline & QA & QB & HA & $\mathrm{HB}$ & QA & $\overline{\text { QB }}$ & HA & HB & $\overline{\mathrm{QA}}$ & $\overline{\mathrm{QB}}$ & HA & HB \\
\hline & \multicolumn{2}{|c|}{$\mathrm{m} 3 / \mathrm{s}$} & \multicolumn{2}{|c|}{$\mathrm{m}$} & \multicolumn{2}{|c|}{$\mathrm{m} 3 / \mathrm{s}$} & \multicolumn{2}{|c|}{$\mathrm{m}$} & \multicolumn{2}{|c|}{$\mathrm{m} 3 / \mathrm{s}$} & \multicolumn{2}{|c|}{$\mathrm{m}$} \\
\hline 0 & 0.477 & 0.477 & 150 & 150 & 0.477 & 0.477 & 150 & 150 & 0.477 & 0.477 & 150 & 150 \\
\hline 0.5 & 0.3698 & 0.477 & 213.68 & 150 & 0.405 & 0.4053 & 192.55 & 150 & 0.4269 & 0.477 & 179.5 & 150 \\
\hline 1 & 0.2358 & 0.263 & 293.22 & 150 & 0.3086 & 0.3336 & 250.2 & 150 & 0.3567 & 0.3768 & 221.4 & 150 \\
\hline 1.5 & 0.0781 & -0.005 & 259.33 & 150 & 0.155 & 0.14 & 255.65 & 150 & 0.2269 & 0.2372 & 238.42 & 150 \\
\hline 2 & 0 & -0.106 & 146.75 & 150 & 0 & -0.0223 & 232.63 & 150 & 0 & 0.0789 & 290.37 & 150 \\
\hline 2.5 & 0 & 0.005 & 87.2 & 150 & 0 & -0.14 & 136.87 & 150 & 0 & -0.2372 & \begin{tabular}{|l|l|}
196.87 \\
\end{tabular} & 150 \\
\hline
\end{tabular}

The variables $Q_{1.25 \theta}^{C}, H_{1.25 \theta}^{C}$ at time $\mathbf{t}=\mathbf{1 . 2 5 \theta}$ : To determine the variables in the middle of the pipe (point $C$ ), at time $\mathrm{t}=1.25 \theta$ we need two characteristics of Bergeron line and the two mans of Bergeron must move simultaneously the characteristics $C^{-}$and $C^{+}$in the $(\mathrm{x}, \mathrm{t})$ plan with celerity $\mp$ a. The first moves backward whereas the second moves forward, having respectively positive and negative slopes $\operatorname{tg} \alpha=\mp a g / \omega$. The Bergeron lines starting simultaneously respectively from points $\mathrm{A}$ and $\mathrm{B}$ at $\mathrm{t}=\theta$, having a known and predetermined flow regime $Q_{\theta}^{A}, H_{\theta}^{A}, Q_{\theta}^{B}, H_{\theta}^{B}$, in order to arrive at point $\mathrm{C}$ at the same time $\mathrm{t}=1.25 \theta$, The intersection of these two lines determines the flow regime at point $\mathrm{C}$, $Q_{1.250}^{C}, H_{1.25 \theta}^{C}$, The equations of the two lines are:

$$
\begin{gathered}
H_{\theta}^{A}-H_{1.25 \theta}^{C}=\operatorname{tg} \alpha *\left(Q_{\theta}^{B}-Q_{1.25 \theta}^{C}\right), \\
H_{\boldsymbol{\theta}}^{B}-H_{\mathbf{1 . 2 5 \theta}}^{C}=-\operatorname{tg} \alpha *\left(Q_{\boldsymbol{\theta}}^{B}-Q_{\mathbf{1 . 2 5 \theta}}^{C}\right) .
\end{gathered}
$$

The procedure is done for the set $\mathrm{C}$, at equidistant successive time steps with time interval of quarter a phase until the phenomenon repeats in an identical indefinite manner, due to the absence of pressure drops. The graphical obtained results (fig. 4), are reported in Table 4.

Table 4

Flow rate and pressure variation at point $\mathrm{C}$

\begin{tabular}{|c|c|c|c|c|c|c|}
\hline \multirow{2}{*}{$\theta$} & \multicolumn{2}{|c|}{$\gamma=1.5$} & \multicolumn{2}{c|}{$\gamma=1.0$} & \multicolumn{2}{c|}{$\gamma=0.7$} \\
\cline { 2 - 7 } & QC & HC & QC & HC & QC & HC \\
\cline { 2 - 7 } & $\mathrm{m} 3 / \mathrm{s}$ & $\mathrm{m}$ & $\mathrm{m} 3 / \mathrm{s}$ & $\mathrm{m}$ & $\mathrm{m} 3 / \mathrm{s}$ & $\mathrm{m}$ \\
\hline 0.25 & 0.477 & 150 & 0.477 & 150 & 0.477 & 150 \\
\hline 0.75 & 0.3683 & 213.675 & 0.4053 & 192.55 & 0.4269 & 179.75 \\
\hline 1.25 & 0.129 & 229.508 & 0.2364 & 207.725 & 0.3068 & 191.575 \\
\hline 1.75 & -0.0556 & 179.775 & 0.0584 & 197.925 & 0.1577 & 196.75 \\
\hline 2.25 & -0.0502 & 116.85 & -0.0812 & 184.975 & -0.0785 & 243.475 \\
\hline 2.75 & 0.0556 & 120.25 & -0.0589 & 101.955 & -0.1572 & 103.55 \\
\hline 3.25 & 0.0502 & 183.025 & 0.081 & 115.15 & 0.0785 & 56.525 \\
\hline
\end{tabular}

Analytical Method based on method of characteristics : the second method is called method of characteristics [9], allows us to deduce the flow rate and pressure variations at different locations in the studied pipeline using formulas below and graphic interpretation $[10,11]$ in (fig.5). 


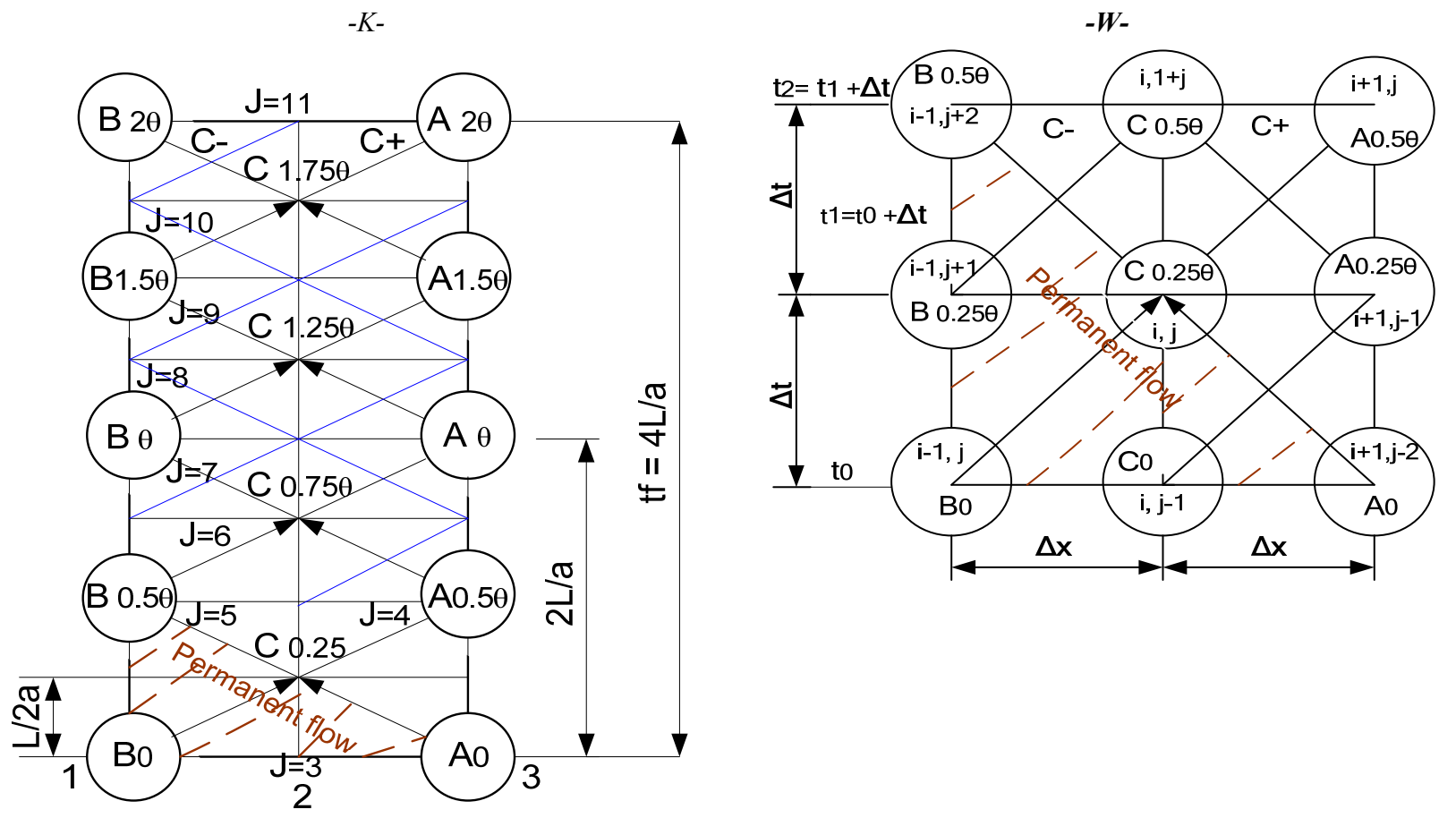

Fig. 5. Diagram (K): for calculating pressures and flow rates at any time at points $A, B$ and $C$ in the plane (x, t) by the method of the characteristics; diagram (W): explanation of the calculation of points: B0, A0, B0.5, A0.5, by the method of the characteristics

Having a permanent flow at point $\mathrm{B}$ that lasts half a phase before the reflection of the overpressure wave and becomes a foreward despression wave. From the following equations [2, 12], momentum equation (dynamic equation): $\frac{d v}{\partial t}$ $+\mathrm{g} \frac{\partial H}{\partial x}+\lambda \frac{v|v|}{2 D}=0$ and mass conservation equation (continuity equation): $\frac{d H}{\partial t}+\frac{a^{2}}{g} \frac{\partial v}{\partial x}$, we obtain a system of two pairs of equations with total derivatives, representatively according to the positive $(\mathrm{c}+)$ and negative $(\mathrm{c}-)$ characteristics, which form the basis of the method of the characteristic, pairs are represented by the straight lines in the plane $(\mathrm{x}, \mathrm{t}),($ fig. 5$)$ :

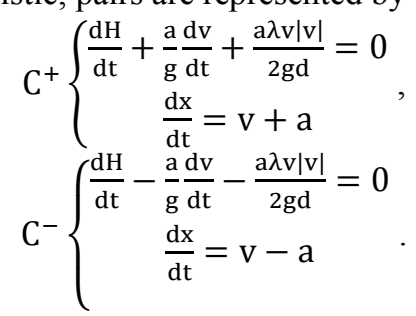

The variables $\boldsymbol{Q}_{\boldsymbol{\theta}}^{\boldsymbol{A}}, \boldsymbol{H}_{\boldsymbol{\theta}}^{\boldsymbol{A}}$ at time $\mathrm{t}=\boldsymbol{\theta}$ : From (4) The equation of the positive characteristic becomes: $H_{\theta}^{A}=H_{0.5 \theta^{-}}^{B} \operatorname{tg} \alpha Q_{\theta}^{A}+\operatorname{tg} \alpha Q_{0.5 \theta}^{B}$, and $\mathrm{Cp}=H_{0.5 \theta}^{B}+\operatorname{tg} \alpha Q_{0.5 \theta}^{B}$, we get:

$$
H_{\theta}^{A}=\mathrm{Cp}-\operatorname{tg} \alpha Q_{\theta}^{A}
$$

and $\operatorname{tg} \alpha=\frac{a}{g s}$ : slope of the Bergeron characteristic line. From (3): $H_{\theta}^{A}=\left(\frac{Q_{\theta}^{A}}{k_{\theta}^{A}}\right)^{2}$, by substituting $\left(k_{\theta}^{A}\right)^{2}$ with $\frac{2\left(\eta Q_{0}\right)^{2}}{2 H_{0}}=\mathrm{Cv}$, we get : $\mathrm{Cv}=\frac{\left(\eta Q_{0}\right)^{2}}{2 H_{0}}$, hence $\left(\frac{Q_{\theta}^{A}}{k_{\theta}^{A}}\right)^{2}=\mathrm{Cp}-\operatorname{tg} \alpha Q_{\theta}^{A}$; the last equation can be transformed into the following second degree equation : $\left(Q_{\theta}^{A}\right)^{2}+2 \mathrm{cv} \operatorname{tg} \alpha Q_{\theta}^{A}-2 \mathrm{cv} \mathrm{Cp}=0$, for a positive solution : $X_{1,1}^{A}=\frac{-B+\sqrt{ } \Delta}{2}>0$, and we obtain :

$$
Q_{\theta}^{A}=-\mathrm{Cv} \operatorname{tg} \alpha+\sqrt{(\mathrm{Cv} \operatorname{tg} \alpha)^{2}+2 \mathrm{Cv} \mathrm{Cp}} .
$$

Initially at point $\mathrm{B}$ for $\mathrm{t}=0.5 \theta$, we have : $H_{0.5 \theta}^{B}=H_{0}=150 \mathrm{~m}$ and $Q_{0.5 \theta}^{B}=Q_{0}=0.477 \mathrm{~m} 3 / \mathrm{s}$. The results are reported (table 5).

\begin{tabular}{|c|c|c|c|c|c|}
\hline $\operatorname{tg} \alpha=\frac{a}{g \omega}$ & $\eta=\left(1-\frac{t}{t_{f}}\right)^{\gamma}$ & $\mathrm{Cv}=\frac{\left(\eta Q_{0}\right)^{2}}{2 H_{0}}$ & $\mathrm{Cp}=H_{0.5 \theta}^{B}+\operatorname{tg} \alpha Q_{0.5 \theta}^{B}$ & $Q_{\theta}^{A} \quad(10)$ & $H_{\theta}^{A} \quad(9)$ \\
\hline $593.70 \mathrm{~s} / \mathrm{m}^{2}$ & 0.353553 & 0.0000948 & $433.1943 \mathrm{~m}$ & $0.23578 \mathrm{~m} 3 / \mathrm{s}$ & $293.2164 \mathrm{~m}$ \\
\hline
\end{tabular}

Table 5

Results of $Q_{\theta}^{A}$ and $H_{\theta}^{A}$, for $\gamma=1.5$ 
The variables $\boldsymbol{Q}_{\mathbf{0 . 5 \theta}}^{A}, \boldsymbol{H}_{\mathbf{0 . 5 \theta}}^{A}$ at time $\mathbf{t}=\mathbf{0 . 5} \boldsymbol{\theta}$ : For the same point A, at time $0.5 \theta$, in this case, the valve closing degree is $64.95 \%$ of the complete cross section (table 1), same calculations are identically, we get $Q_{0.5 \theta}^{A}=0.36975 \mathrm{~m} 3 / \mathrm{s}$ and $H_{0.5 \theta}^{A}=213.612 \mathrm{~m}$. Say a total applied pressure, at point $\mathrm{A}$, on $\mathrm{t}=\theta$, at the arrival of the reflection with to the valve whose closing degree at this moment is $35.35 \%$ of the full cross section $(\gamma=1.5)$, the value of the pressure is $293.21 \mathrm{~m}$, will be compared with the predetermined valued deduce from the graphical Bergeron method, that is $293.22 \mathrm{~m}$, giving practically the same value.

The variables $\boldsymbol{Q}_{\boldsymbol{\theta}}^{\boldsymbol{B}}, \boldsymbol{H}_{\boldsymbol{\theta}}^{\boldsymbol{B}}$ at time $\mathbf{t}=\boldsymbol{\theta}$ : In order to determine this variables, we need two equations; the first one is the negative characteristic, having a starting point as point $\mathrm{A}$ at time $\mathrm{t}=0.5 \theta$, in this case, the propagating wave moves backward and arrives at point $\mathrm{B}$ at time $\mathrm{t}=\theta$, the second equation is the horizontal line corresponding to the pressure load which constantly equal to $H_{0}=150 \mathrm{~m}$, from (4), we can write : $H_{\theta}^{B}=H_{0.5 \theta}^{A}+\operatorname{tg} \alpha *\left(Q_{\theta}^{B}-Q_{0.5 \theta}^{A}\right)$, so $\mathrm{CM}=H_{0.5 \theta}^{A}-$ $\operatorname{tg} \alpha * Q_{0.5 \theta}^{A}$, we get the following equation:

$$
Q_{\theta}^{B}=\left(H_{\theta}^{B}-C M\right) / \operatorname{tg} \alpha
$$

Results of calculations of $Q_{\theta}^{B}$ et $H_{\theta}^{B}$,for $\gamma=1.5$

\begin{tabular}{|c|c|c|}
\hline$H_{\theta}^{B}=H_{0}$ & $\mathrm{CM}=H_{0.5 \theta}^{A}-\operatorname{tg} \alpha * Q_{0.5 \theta}^{A}$ & $Q_{\theta}^{B}=\left(H_{\theta}^{B}-C M\right) / \operatorname{tg} \alpha$ \\
\hline$=150 \mathrm{~m}$ & $=213.612-593.7 * 0.36975=-5.900575 \mathrm{~m}$ & $=150+5.900575 / 593.7=0.26259 \mathrm{~m} 3 / \mathrm{s}$ \\
\hline
\end{tabular}

The calculations for different times are repeated in an identical manner for several phases in $[0-9 \theta]$ and at intermediate times $[0.5 \theta-8.5 \theta]$ for points $\mathrm{A}$ and $\mathrm{B}$. The results for $\left(Q_{\theta}^{B}, H_{\theta}^{B}\right)$ are in (Table 6).

The variations $\boldsymbol{Q}_{\mathbf{0 . 7 5 \theta}}^{C}, \boldsymbol{H}_{\mathbf{0 . 7 5 \theta}}^{C}$ : In order to determine this variables, two negative and positive characteristics are necessary, respectively for which the first is the backward wave propagating against the positive flow having A as a starting point at $\mathrm{t}=0.5 \theta$, in the same time, the second is a forward wave, has B as starting point, and propagates with the flow; these two characteristic lines meets at point $\mathrm{C}$ and in the $(\mathrm{x}, \mathrm{t})$ plan corresponding to time $\mathrm{t}=0.75 \theta$ at this location. From (5) et (6) we can write, respectively the two positive and negative characteristic lines CP et CM as follows:

$H_{0.75 \theta}^{C}=H_{0.5 \theta}^{B}-\operatorname{tg} \alpha *\left(Q_{0.75 \theta}^{C}-Q_{0.5 \theta}^{B}\right)$, so : $\mathrm{Cp}=H_{0.5 \theta}^{B}+\operatorname{tg} \alpha Q_{0.5 \theta}^{B}, H_{075 \theta}^{C}=H_{0.5 \theta}^{A}+\operatorname{tg} \alpha *\left(Q_{0.75 \theta}^{C}-Q_{0.5 \theta}^{A}\right)$, from where : $\mathrm{CM}=H_{0.5 \theta}^{A}-\operatorname{tg} \alpha Q_{0.5 \theta}^{A}$; by adding the above two equations we get the variables at point $\mathrm{C}[12,13]$.

$$
\begin{gathered}
H_{0.75 \theta}^{C}=(C p+C M) / 2, \\
Q_{0.75 \theta}^{C}=(C p-C M) / 2 \operatorname{tg} \alpha .
\end{gathered}
$$

Results of calculations of $Q_{\mathbf{0 . 7 5 \theta}}^{B}$ and $H_{0.75 \theta}^{B}$, for $\gamma=1.5$

\begin{tabular}{|c|c|c|c|}
\hline $\mathrm{Cp}=H_{0.5 \theta}^{B}+\operatorname{tg} \alpha Q_{0.5 \theta}^{B}$ & $\mathrm{CM}=H_{0.5 \theta}^{A}-\operatorname{tg} \alpha Q_{0.5 \theta}^{A}$ & $H_{0.75 \theta}^{C}=(C p+C M) / 2$ & $Q_{0.75 \theta}^{C}=(C p+C M) / 2 \operatorname{tg} \alpha$ \\
\hline $433.162675 \mathrm{~m}$ & $-5.878475 \mathrm{~m}$ & $213.64 \mathrm{~m}$ & $0.3675 \mathrm{~m} 3 / \mathrm{s}$ \\
\hline
\end{tabular}

The results $Q_{0.75 \theta}^{C}, H_{0.75 \theta}^{C}$ are presented in (Table 7). The remaining calculations for point $\mathrm{C}$ at time steps $0.25 \theta$, $1.25 \theta, 1.75 \theta, 2.25 \theta, 2.75 \theta, 3.25 \theta$ and $3.75 \theta$, using the two equations of the positive and negative characteristics. The intersection of the two lines, gives the variables at that point.

For all the variables $\mathrm{H}$, Q of the points: B, C and A, at different times, a program code written in Fortran (Fortran 77) was established and validated by the results determined in advance by the Bergeron graphic method. The results obtained by this method of the characteristics are presented in the figures below, for the values of $\theta$ : [0 - $9 \theta$ ] and for the three cases: $\gamma=1.5, \gamma=1$ and $\gamma=0.7$, for closing time $t_{c l}=2 \theta$.
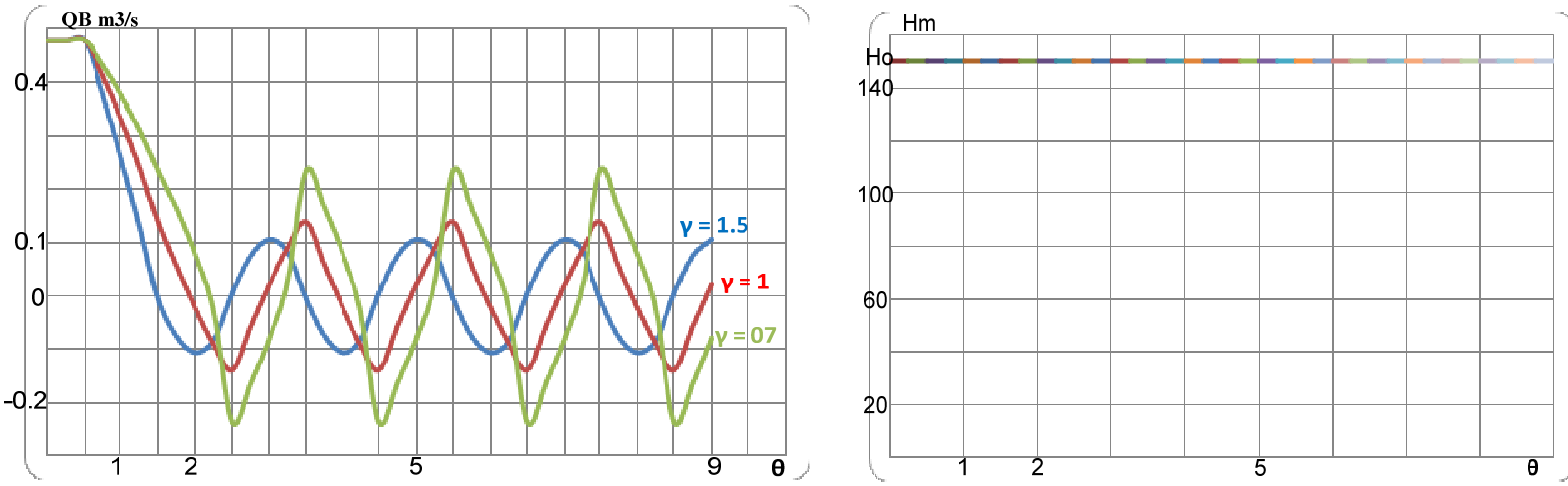

Fig. 6. Variations of flow rate $Q_{B}(\mathrm{~m} 3 / \mathrm{s})$, at $\operatorname{tank}($ point $B)$, versus phase $\theta$, for closing time $t_{c l}=\mathbf{2 \theta}$

Fig. 7. Variations of pressure $H_{B}(\mathrm{~m})$ at tank (point B), versus phase $\theta$, for closing time $t_{c l}=\mathbf{2 \theta}$ 


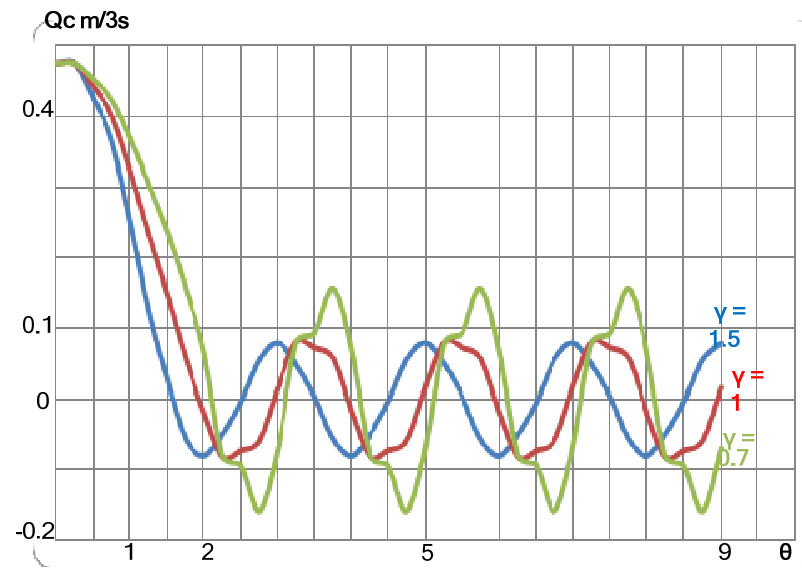

Fig. 8. Variations of flow rate $Q_{C}\left(\mathrm{~m}^{3} / \mathrm{s}\right)$ at middle of pipe (point $\mathrm{C}$ ), versus phase $\theta$, for closing time $t_{c l}=2 \theta$

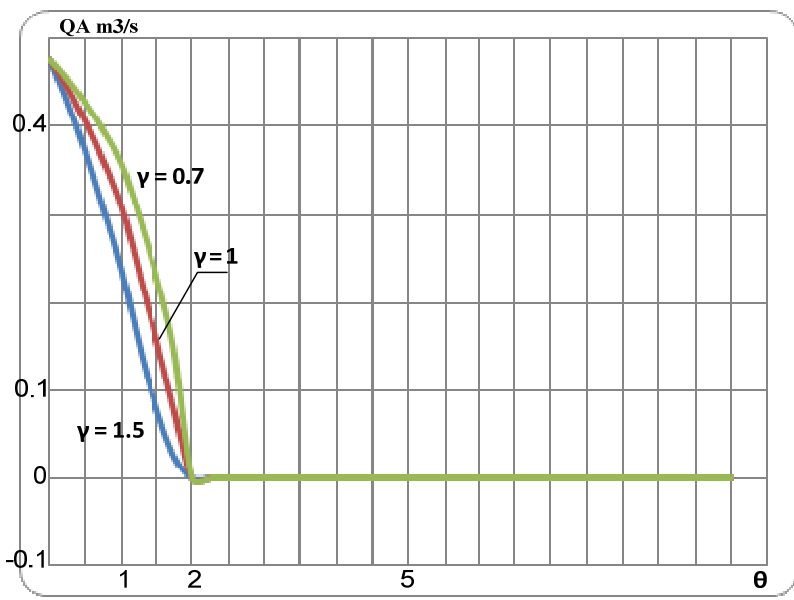

Fig. 10. Variations of flow rate $Q_{A}\left(\mathrm{~m}^{3} / \mathrm{s}\right)$ at valve (point $\mathrm{A}$ ), versus phase $\theta$, for closing time $t_{c l}=\mathbf{2 \theta}$

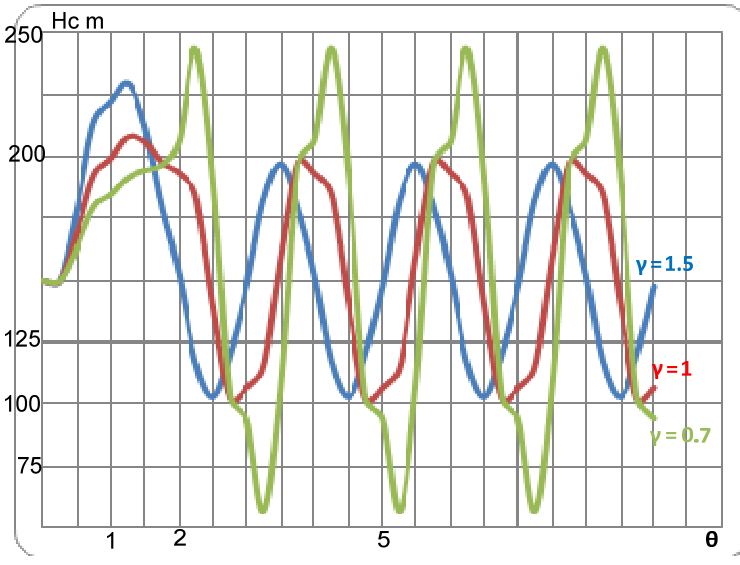

Fig. 9. Variations of pressure $H_{C}(\mathrm{~m})$ at point $C$, versus phase $\theta$, for closing time $t_{c l}=\mathbf{2 \theta}$

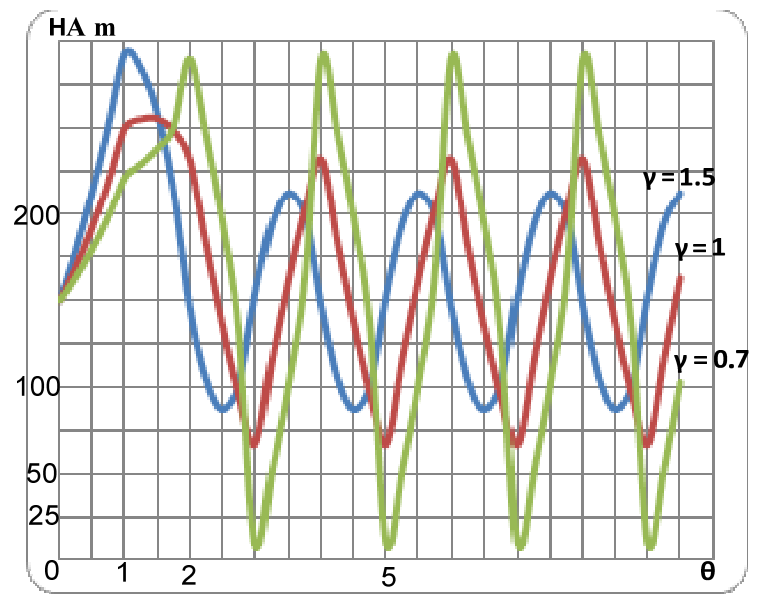

Fig. 11. Variations of pressure $H_{A}(\mathrm{~m})$ at valve (point A), versus phase $\theta$, for closing time $t_{c l}=\mathbf{2 \theta}$

This program is also used and exploited for a different closing times $t=0.25 \theta, \theta, 2 \theta$ and $t=3 \theta$, for a case of $\gamma=1.5$, because this last parameter gives efficient results of overpressure and depressure, with respect to the two parameters of $\gamma=1$ and $\gamma=0.7$, for the values of $\theta$ in $[0 ; 9 \theta]$. The results are presented in the figures below.

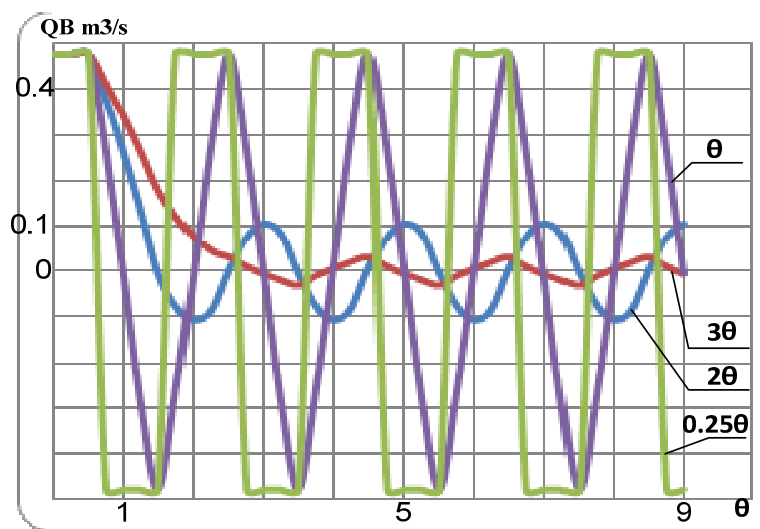

Fig. 12. Variations of flow rate $Q_{B}\left(\mathrm{~m}^{3} / \mathrm{s}\right)$, at tank (point $B$ ), depending on different closing times $t_{c l}=0.25 \theta, \theta .2 \theta$ and $3 \theta$, for $\gamma=1.5$

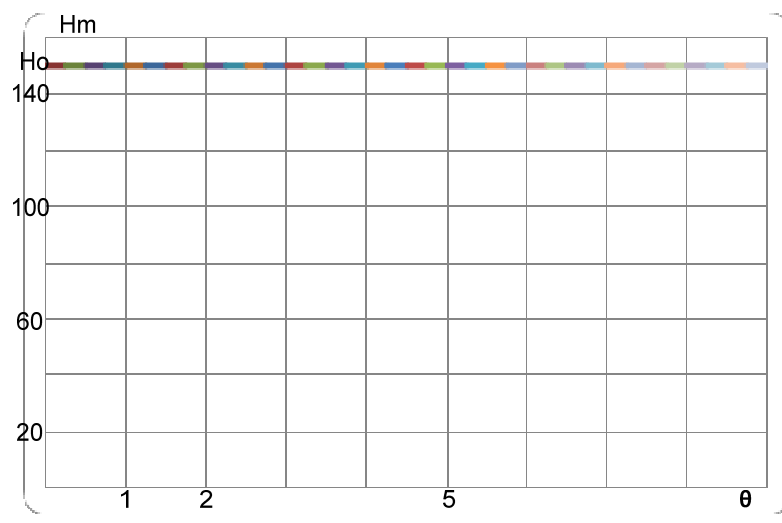

Fig. 13. Variations of pressure $H_{B}(\mathrm{~m})$, at tank (point B), depending on different closing times $t_{c l}=0.25 \theta, \theta .2 \theta$ and $3 \theta$, for $\gamma=1.5$ 


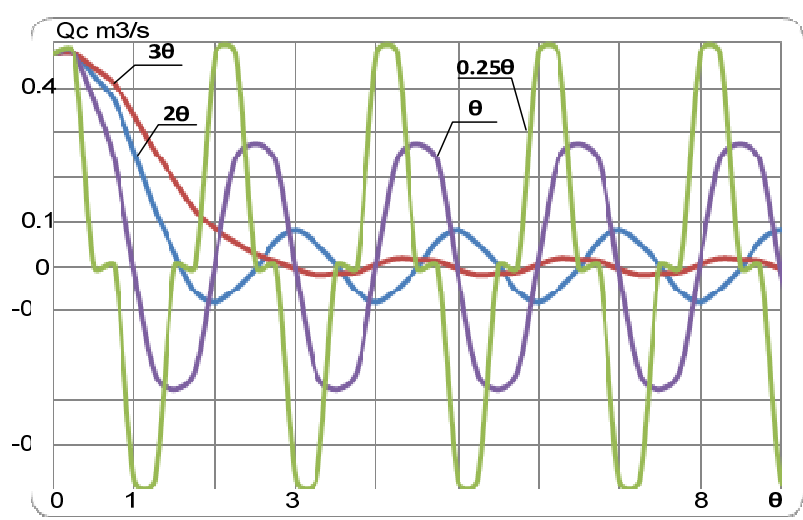

Fig. 14. Variations of flow rate $Q_{C}\left(\mathrm{~m}^{3} / \mathrm{s}\right)$, at point $\mathrm{C}$, for different closing times $t_{c l}=0.25 \theta, \theta, 2 \theta$ and $3 \theta$, for $\gamma=1.5$

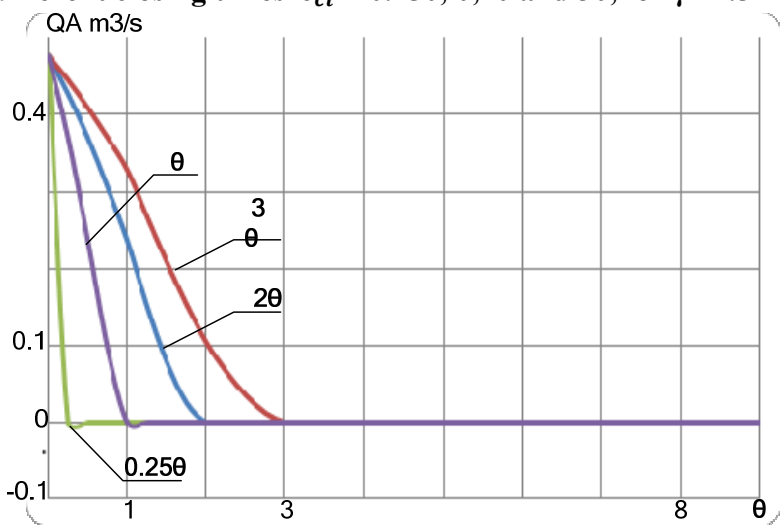

Fig. 16. Variations of flow rate $Q_{A}\left(\mathrm{~m}^{3} / \mathrm{s}\right)$, at point $A$, for different closing times $t_{c l}=0.25 \theta, \theta .2 \theta$ and $3 \theta$, for $\gamma=1.5$

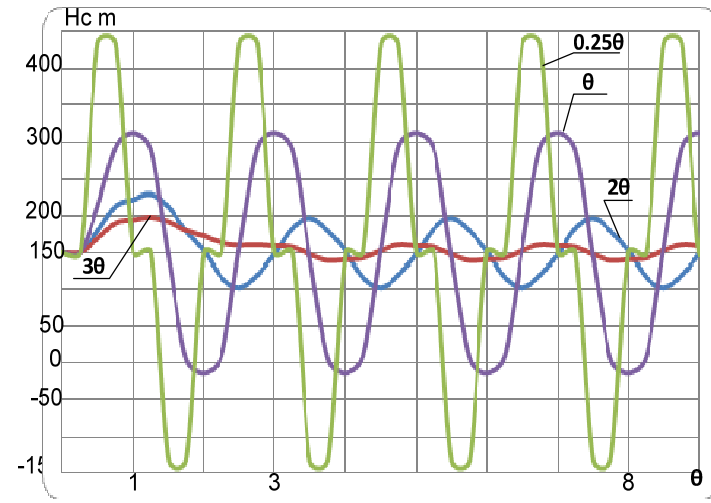

Fig. 15. Variation of pressure $H_{C}(\mathrm{~m})$, at point $\mathrm{C}$, for different closing times $t_{c l}=0.25 \theta, \theta .2 \theta, 3 \theta$, for $\gamma=1.5$

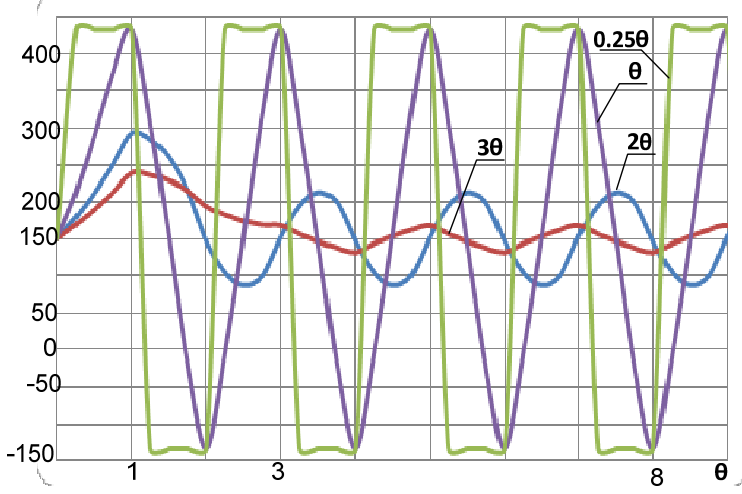

Fig. 17. Variation of pressure $H_{A}(\mathrm{~m})$, at point $A$, for different closing times $t_{c l}=0.25 \theta, \theta .2 \theta, 3 \theta$, for $\gamma=1.5$

\section{Conclusions}

The results obtained by the two methods, Bergeron's graphical method and the numerical method called the characteristic method, are identical, which confirms the reliability and accuracy of the calculation results.

From the results of the numerical method (characteristic method), from the values of $H_{\theta}^{A}$, for a closure time $t_{c l}=2 \theta$, we notice that in $[0 ; 9 \theta]$, that the results relative to the $\gamma=0.7$, at the point $\mathrm{A}$ (valve), the overpressures and the depressure respectively are repeated in a periodic manner and indefinite due to the absence of loss of pressure; the maximum value equal to $290.7 \mathrm{~m}$ and a minimum value equal to $9.7 \mathrm{~m}$. These values are remarkable and considerable compared with those resulting for $\gamma=1\left(H_{\max }^{A}=232.55 \mathrm{~m}\right.$ and $\left.H_{\min }^{A}=67.45 \mathrm{~m}\right)$ and $\gamma=1.5\left(H_{\max }^{A}=212.73 \mathrm{~m}\right.$ and $\left.H_{\min }^{A}=87.26 \mathrm{~m}\right)$ which a repeat periodically. These pressure values for $\gamma=0.7$ can then exceed the load-carrying capacity of the materials for the pipes with low resistance, which is why they can lead to the destruction of pipe construction following the process of this phenomenon of a water hammer; $\gamma=1.5$ gives reliable results compared with the $\gamma=1$ which results in the following relations: $H_{\max }^{A}(\gamma=1.5)<H_{\max }^{A}(\gamma=1)<H_{\max }^{A}(\gamma=0.7)$ and $H_{\min }^{A}(\gamma=1.5)>H_{\min }^{A}(\gamma=1)>H_{\min }^{A}(\gamma=0.7)$.

From the following figures: (Figure $12-17$ ), we make the following conclusions:

For $0<t_{c l} \leq \theta$, the maximum values of $\mathrm{H}_{\max }=433 \mathrm{~m}$ are always given for valve (point $\mathrm{A}$ ) and in the middle of the pipe (point $\mathrm{C}$ ), this condition being considered as an sudden (progressive) closure. This value can also be obtained using the Zhukovsky formula. For $t_{c l}>\theta$, this closure is considered as a slow closing, the more closing time is long $\left(t_{c l}>\theta=\frac{2 l}{a}\right.$ ) the more protection of hydraulic infrastructure equipment against the phenomenon of water hammer (pipes, valves, meters, check valves, ...).

\section{Вплив вибору параметра $\gamma$ на зміну тиску і витрати, при закритті засувки у кінці трубопроводу з безнапірним потоком}

\section{Б. Хоггас, С. Хезіл}

Анотація. Вивчення зміни тиску і витрати в трубопроводі, який з'єднаний з резервуаром (точка В), який має постійний рівень води упродовж перехідного режиму, що відбувається під час закриття засувки розташованого на кінці горизонтального самопроточного трубопроводу (точка А). Закриття иієї засувки, виконується трьома способами - 
миттєвим, раптовим або поступовим. Операція закриття засувки виражається через функиію від часу $t$ і параметра $\gamma$, щяо характеризує форму закриття секиї ичієї засувки, ү може змінюватися в інтервалі [0,7-1,5]. Змінні тиску і витрати води в точках $\left(Q_{t}^{A}, H_{t}^{A}\right),\left(Q_{t}^{B}, H_{t}^{B}\right) i\left(Q_{t}^{C}, H_{t}^{C}\right)$, в будь-який момент часу $t$, відповідно, засувки, резервуар і в середині трубопроводу (точка C), будуть визначатися двома способами: графічним методом, відомим якметод Бержерона, а другий є аналітичним методом характеристики.

Ключові слова: перехідний режсим, безнапірний трубопровід, миттєвий, раптовий $і$ поступовий спосіб, змінні тиску $i$ витрати, графічний метод Бержерона, аналітичний метод характеристики.

\title{
Влияние выбора параметра $\gamma$ на изменение давления и расхода, при закрытии задвижки в конце трубопровода с безнапорным потоком
}

\author{
Б. Хоггас, С. Хезил
}

Аннотация. Изучение изменения давления и расхода в трубопроводе, который соединен с резервуаром (точка В), имеющим постоянный уровень воды в течение переходного режима, происходящего во время закрытия задвижки расположенного на конце горизонтального безнапорного трубопровода (точка А). Закрытие этой задвижки выполняется тремя способами мгновенным, внезапным или постепенным, операчия закрытия задвижки выражается через функиию от времени $t$ и параметра $\gamma$, характеризующую форму закрытия секции этой задвижки, у может изменяться в интервале [0,7-1,5]. Переменные давления и расхода воды в точках $\left(Q_{t}^{A}, H_{t}^{A}\right),\left(Q_{t}^{B}, H_{t}^{B}\right) u\left(Q_{t}^{c}, H_{t}^{c}\right)$, в любой момент времени $t$, соответственно, в задвижки, резервуар и в середине трубопровода (точка С), будут определяться двумя методами - графическим методом Бержерона и аналитическим методом характеристик.

Ключевые слова: переходный режим, безнапорній трубопровод, мгновенный, внезапный и постепенный способ, переменные давления и расхода, графический метод Бержерона, аналитический метод характеристик.

\section{References}

1. Publication of all papers presented at the International Conference on "Pressure Surges" held by bhra fluid engineering, Great Britain, in the years 1976, 1980, 1986, 1992, 1996, 2000.

2. Wylie, E.B. and Streeter, V.L. FluidTransits, New York, 1983.

3. Stephenson, D. Development in water science 19. PIPEFLOW ANALYSIS, Amsterdam-oxford-New york-tokyo. - 1984. pp. $175-183$.

4. Tijsseling, A.S. and Anderson, A. "Thomas Young's research on fluid transients: 200 years on. BHR Group", Proc. of the 10th Int. Conf. on Pressure Surges (Editor S. Hunt), Edinburgh, United Kingdom. - 2008. - pp. 21 - 33, https://www.researchgate.net/publication/280623926_Thomas_Young's_research_on_fluid_transients_200_years_on.

5. Bergeron, L. Etude des variations de régime dans les conduites d'eau: solution graphique génerale, revue génerale de l'hydraulique, Paris. - 1935. - vol. 1, - pp. 12 - 69.

6. Guinot, V. "Riemann Solvers for Water Hammer Simulations by Godunov Method", Int. J. Numer. Methods. Eng. - 2002. Vol. 49, - pp. $851-870$.

7. Brunone, B., Golia, U.M. and Greco, M., "Modelling of Fast Transients by Numerical Methods", Proc. Int. Conf. on Hydr.Transients With Water Column Separation, IAHR, Valencia, Spain. - 1991. pp. 273 - 280.

8. Tijsseling, A.S. and Anderson, A. "Johannes von Kries and the history of water hammer", ASCE Journal of Hydraulic Engineering, 133, pp. 1-8, DOI: 10.1061/(ASCE)0733-9429(2007)133:1(1)

9. Jovic, V. (1995), "Finite Element and Method of characteristics Applied to water Hammer Modeling", Int. J. for Engng. Modeling, 8(3\&4), pp. 21 - 28.

10. Tijsseling, A.S. and Anderson, A. "A precursor in water hammer analysis -rediscovering Johannes von Kries". BHR Group, Proc. of the 9th Int. Conf. On Pressure Surges (Editor S.J. Murray), Chester, United Kingdom. - 2004. - pp. 739 - 751.

11. Mambretti, S. (2014), Water Hammer Simulations, Politecnico di Milano, Italy.

12. Ghidaoui, M.S. and Karney, B.W. "Equivalent Differential Equations in Fixed-Grid Characteristics Methods", J. Hydraul. Eng. - 1994. - 120(10), - pp. 1159 - 1175.

13. Sang-Gyun KIM, Kye-Bock LEE, Kyung-Yup KIM. "Water hammer in the pump-rising pipeline system with an air chamber", Journal of hydrodynamics, SER. B. - 2015. - vol. 26, no. 6, - pp. 960-964. 